\author{
Dariusz Dobrucki \\ mgr inż. \\ Politechnika Wrocławska \\ Wydział Budownictwa Lądowego i Wodnego \\ Zakład Dróg i Lotnisk \\ dariusz.dobrucki@pwr.edu.pl
}

DOI: 10.35117/A_ENG_17_08_03

\title{
Sand equivalent as an evaluation of unbound mixtures suitability for road pavement layers.
}

\begin{abstract}
In the article a review of sand equivalent evaluation methods of mineral mixtures for unbound road pavement layers was shown. Considering that there are various test methods and different evaluation criterions of these materials suitability, the need to develop unified sand equivalent method for aggregates and unbound mixtures in Poland was pointed. The objective method and limiting values of sand equivalent test were suggested. It was done based on laboratory examinations coupled with California bearing ratio tests.
\end{abstract}

Keywords: Sand equivalent; Unbound mixture; Base layer

\section{Introduction}

Layers of unbounded aggregates are very often performed on Polish roads. The assessment of the suitability of blends for such layers is based on a number of different criteria, including the "sand equivalent". The requirements for this parameter are different depending on the rules that can be invoked. In accordance with PN-S-06102: 1997 [12] the mineral mixture for unbounded, mechanically stabilized base should have a sand ratio of $30 \div 70 \%$. According to "WT-4 Technical Requirements" [5], the minimum sand value should be $35 \%$ for subfloor, $40 \%$ for substructure and $45 \%$ for substructure. The same values are given in the "Catalog of typical susceptible and semi-rigid pavements". [4] The technical specification [6], developed by GDDiK, lowers the minimum value of the sand index to $35 \%$ for substructures intended to be higher than average and 30\% for other layers.

Perhaps the discrepancies in the criteria used for the sand equivalent are due to the attempts to adapt the rules to the evolving standards describing how this parameter is determined. For almost 40 years the sand index was determined on the basis of the industry standard [2] of 1964. In 2001, a new European standard PN-EN 933-8 [9] was introduced, which was modified in 2012 and 2015 [10, 11]. In all the standards mentioned, the sand equivalent designation remains the same. However, the method of preparation of the test sample is changed. Laboratory practice shows that the preparation of samples has a definite effect on the outcome of the study.

Similar divergences in the sand equivalent assessment are also found in the work of foreign research institutions. The minimum values of the sand ratio, depending on the country and the specific standards used, are different [1]. Table 1 shows the recommended sand-pit 
values used in Greece, the USA, and France. The differences also apply to the preparation of laboratory samples. The Greek requirements refer to the sample size $0 / 2$, while in the US the sand ratio is used for a particle size of $0 / 4,76$ (sieve number 4) $[3,13]$

Tab. 1. Recommended sand equivalent value in Greece, USA, and France [1]

\begin{tabular}{|l|l|l|l|}
\hline $\begin{array}{l}\text { Aggregate } \\
\text { designed for: }\end{array}$ & $\begin{array}{l}\text { Greek } \\
\text { specifications }\end{array}$ & $\begin{array}{l}\text { ASTM 2940, } \\
\text { ASTM 3515 } \\
\text { (USA) }\end{array}$ & French specifications \\
\hline $\begin{array}{l}\text { Unbounded the basic } \\
\text { foundation }\end{array}$ & $\geq 50$ & $\geq 35$ & $\geq 40$ or $\geq 50$ or $\geq 60^{*}$ \\
\hline $\begin{array}{l}\text { Unbounded support } \\
\text { bases }\end{array}$ & $\geq 40$ & $\geq 35(\geq 30)$ & \\
\hline
\end{tabular}

* Depending on the type (code) of the mineral mixture - code C, or B, or A, respectively.

Various assessments and methods for sand equivalent indicate the need for a unified assessment of this parameter for aggregates and unbound mixtures.

\section{Preparation of samples for determining the sand equivalent}

Standard BN-64 / 8931-01 [2] requires the screened soil or aggregate to be screened through a square mesh screen \# $4 \mathrm{~mm}$. At the time of screening, the sample should have a low humidity to avoid loss of fine particles. The $0 / 4$ fraction is used to denote the sand ratio. The result of the study is described by the symbol WP.

According to PN-EN 933-8: 2001 [9], the sand equivalent test shall be carried out on a sample of $0 / 2 \mathrm{~mm}$ aggregate sifted from the mineral mix at a moisture content of less than $2 \%$. The result of the test should be the SE symbol. Annex A to the standard allows the test at $0 / 4 \mathrm{~mm}$, then the test result should be described by the symbol $\mathrm{SE}_{4}$.

The standard PN-EN 933-8: 2012 [10] makes a definite change. After fractionation $0 / 2$, the dust content of the sample should be determined. If the dust content is less than $10 \%$, the test shall be carried out without correction of the composition. If the dust content is greater than $10 \%$ then the composition of the test sample should be adjusted so that the dust content is $10 \%$. The sand markers designated in this way must be described by the symbol SE (10). Appendix A to the standard allows a test on a particle size of $0 / 4 \mathrm{~mm}$. The composition of the sample shall not be adjusted in terms of the content of the dusty fraction, and the result obtained during the test shall be the symbol $\mathrm{SE}_{4}$.

Standard PN-EN 933-8: 2015 [11] leaves the same way of preparing a 0/2 sample as in the standard from 2012. Annex A was accepted in which 0/4 fraction was allowed, but similar to fraction $0 / 2$, the composition should be adjusted with a dust content greater than $10 \%$. It is interesting to note that the $\mathrm{SE}_{4}$ symbol has been left behind for such a designated sand index, which may mislead the results of the study if it fails to pay attention to the year of issue of the test standard..

In summary, there are four variants of sample preparation for determining the sand ratio. The specimen may have a grain size of $0 / 2$ or $0 / 4 \mathrm{~mm}$ and in either case it may be a sample with a fine-grained or no-adjustment fraction. The sample preparation methods are presented in Table 2. 
Tab. 2. Samples for testing the sand equivalent according to different standards

\begin{tabular}{|l|l|l|}
\hline \multirow{2}{*}{ Standard No. } & Researched fraction \\
\cline { 2 - 3 } & $0 / 2 \mathrm{~mm}$ & $0 / 4 \mathrm{~mm}$ \\
\hline BN-64/8931-01 & - & without correction \\
\hline PN-EN 933-8:2001 & without correction & without correction \\
\hline PN-EN 933-8:2012 & without correction & $\begin{array}{l}\text { correction of the dust } \\
\text { content }\end{array}$ \\
\hline PN-EN 933-8:2015 & correction of the dust content & $\begin{array}{l}\text { correction of the dust } \\
\text { content }\end{array}$ \\
\hline
\end{tabular}

\section{Laboratory tests}

Testing in compliance with the 2001 and 2015 standards makes it possible to compare all four methods of sample preparation for a sand equivalent. Expanding the scope of the CBR test for blends with different sand equivalents will allow us to assess the suitability criteria used for unbound layers.

\section{Sand equivalent according to norms from 2001 and 2015}

For the study, melamine was chosen with a grain size of $0 / 31.5 \mathrm{~mm}$. The mineral mix was divided into narrow fractions to very accurately control the composition of each test mixture. An optimum mixture was chosen, whose grading curve was in the middle of the field determined by the limit grading curves for substructures, as required by WT-4 [5]. The proportions between $0 / 0.063$ and $0.063 / 2 \mathrm{~mm}$ were then changed. Finally, six blends were prepared, the grain sizes of which are shown in Figure 1. The results of the sand equivalent test for various dusty particle contents and the various sample preparation methods are shown in Figure 2.



1. Curves of particle size distribution of different blends of dust and sand fraction and boundary curves for mineral mixture on substructure according to WT-4. 


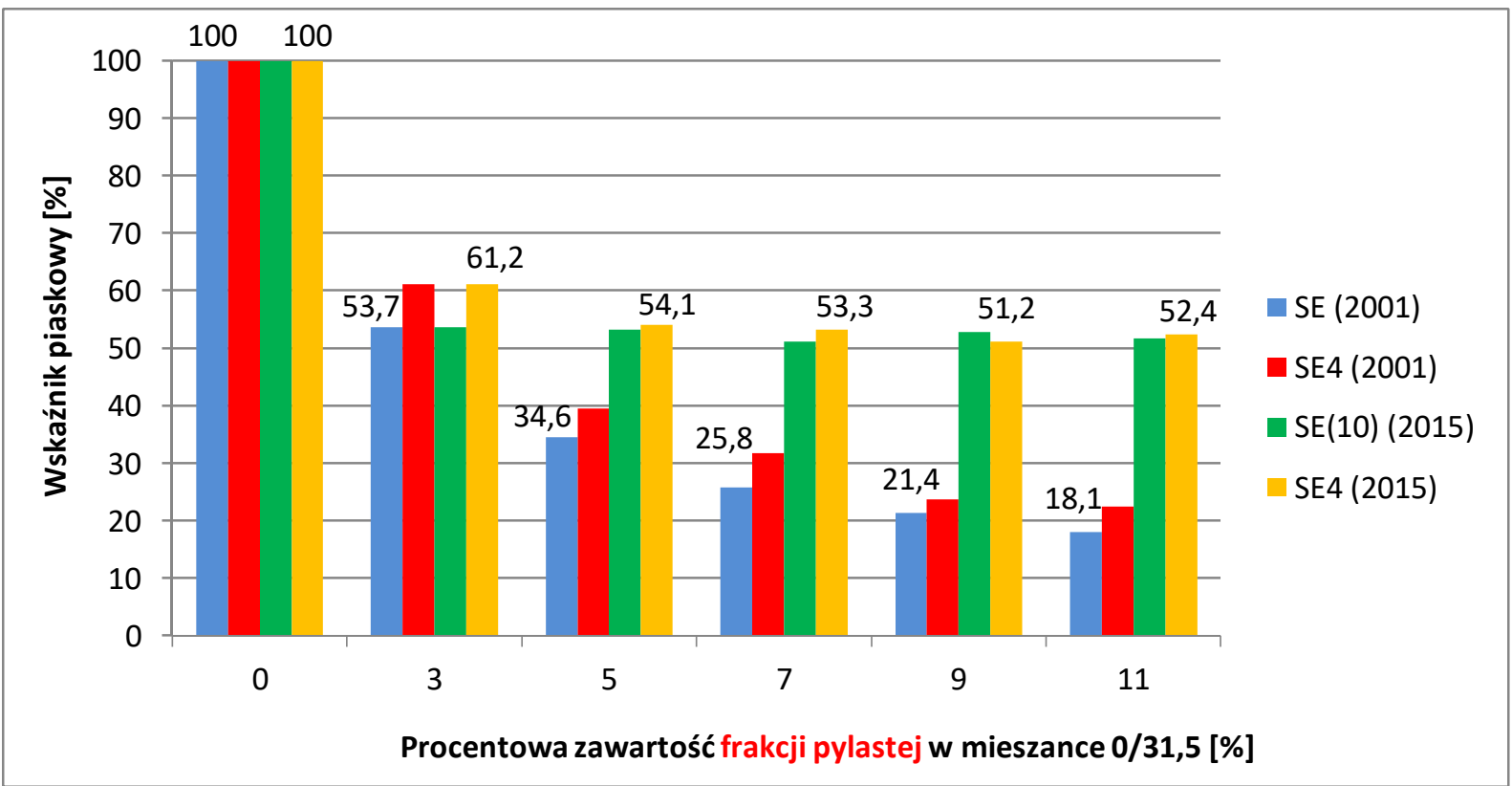

2. Sand equivalents for different mineral dust content

As a result of a study conducted in accordance with the 2015 standard, it was found that all blends are characterized by sand equivalents greater than $50 \%$. Accordingly, they meet the requirements of WT-4 and can be used for auxiliary and basic support. The criterion that allows all blends, regardless of dust content, is no longer authoritative.

When preparing samples for testing according to the 2001 standard only for blends with a dust content of $0 \%$ and $3 \%$, sand rates greater than $40 \%$ were obtained. Consequently, the remaining mixtures should not be used either for auxiliary substructures or for substructures. In this case the question arises: are the limits of the sand ratio $-40 \%$ and $45 \%$ (included in [5]) not too stringent?

\section{Sand equivalents designated for fractions $0 / 2$ and $0 / 4$}

Three previously designed mineral mixtures with a dust content of $3 \%, 7 \%$, and $11 \%$ were selected for study (Figure 1). Then, for each of the three blends, the proportions between $2 / 4$ and $4 / 8 \mathrm{~mm}$ were changed. Fraction $2 / 4$ was from $0 \%$ to $17 \%$. For mixtures without fraction $2 / 4$, the sand index determined at fraction $0 / 2$ is equal to the index denoted at fraction $0 / 4$. Finally, $3 \times 7=21$ mineral mixtures were prepared, the grain sizes of which are shown in Figure 3. The sandwiches SE4 were prepared according to the 2001 standard for such mixtures. The results are shown in Figure 4. 


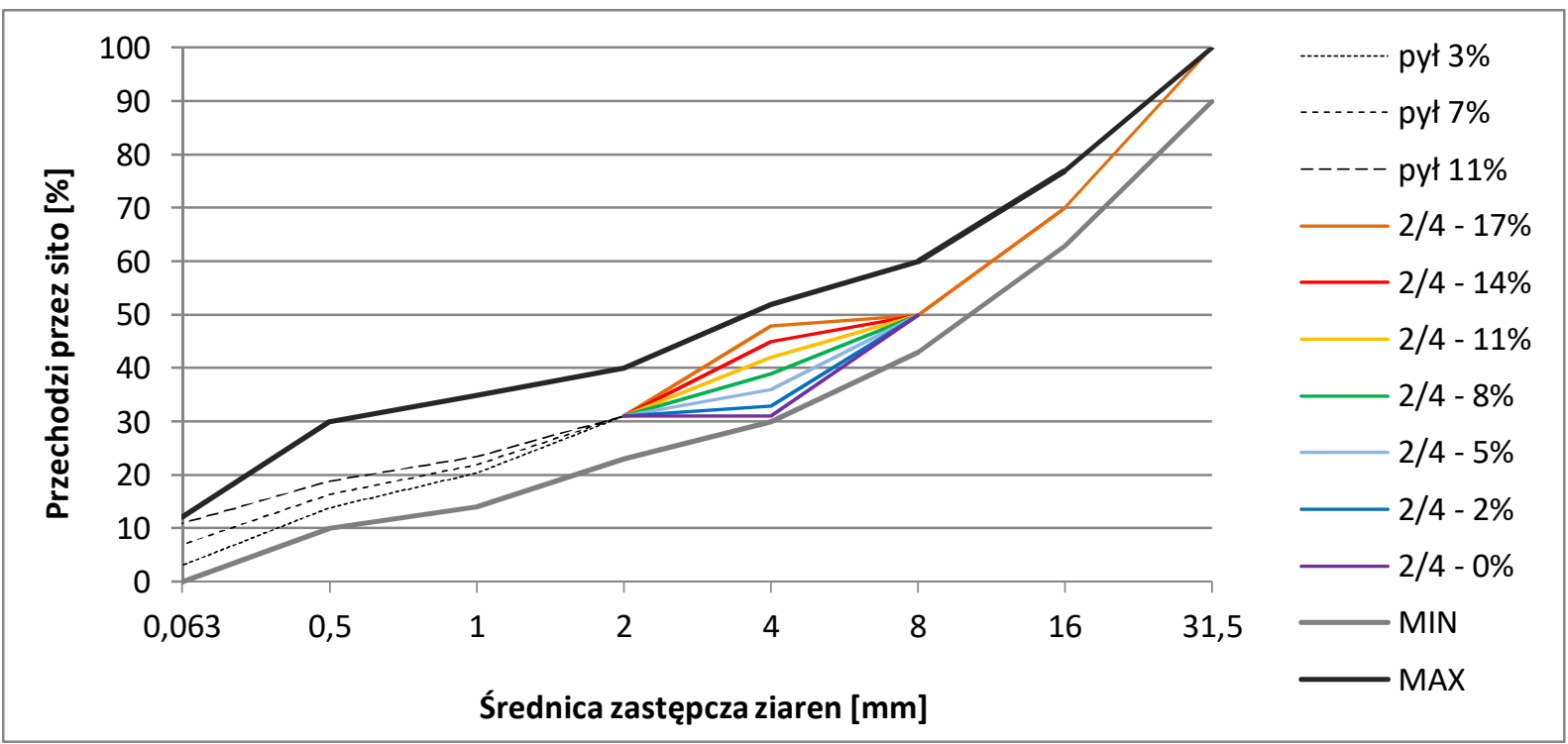

3. The particle size distribution curves of mixtures containing different amounts of silt fraction and the fraction 2/4 and boundary curves for a mixture of mineral subbase according to WT-4

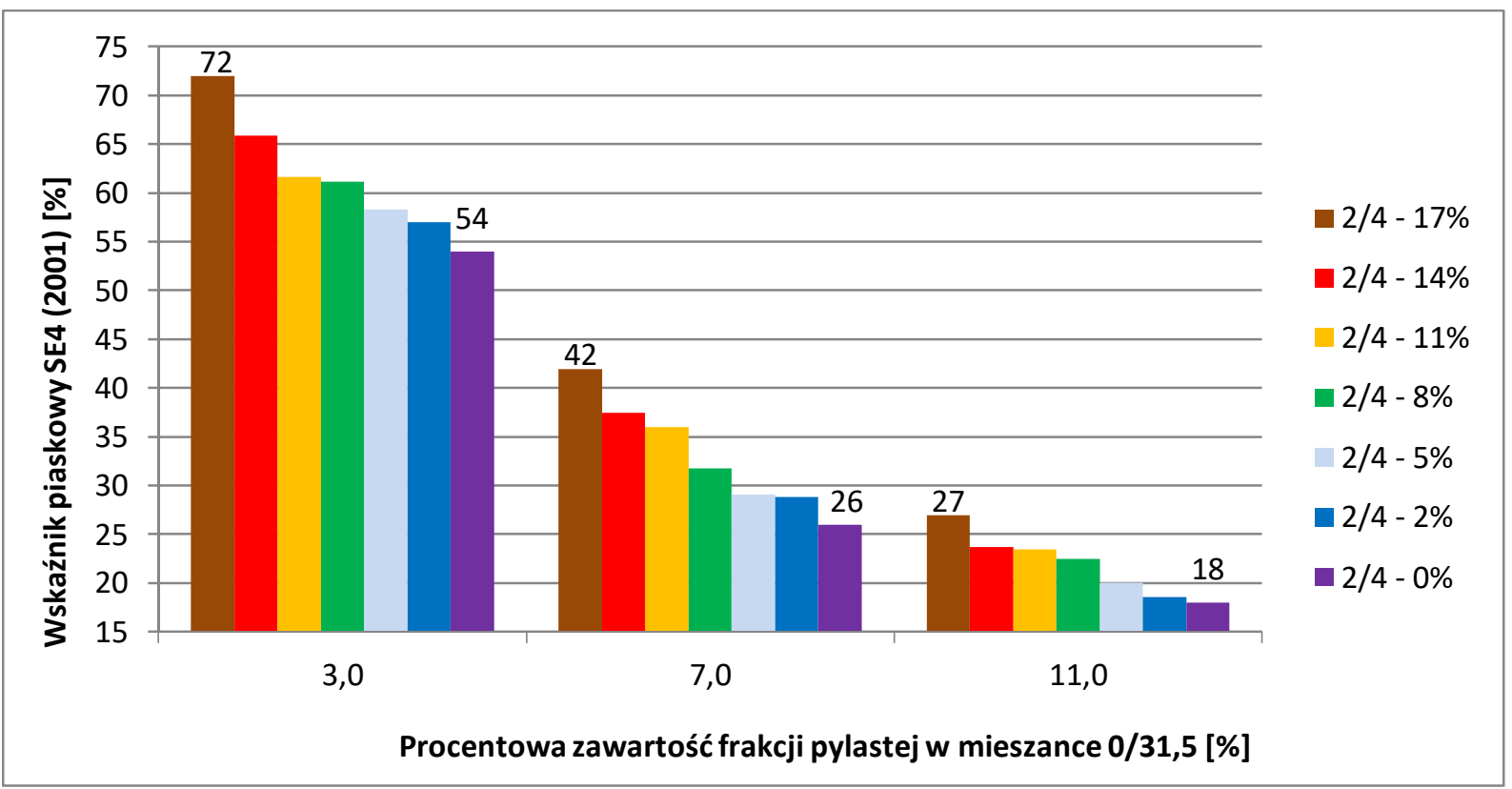

4. SE4 sand equivalents for various dusty content and different content of fraction $2 / 4$

In conclusion of this study, it should be noted that the maximum differences between the sand ratio equivalents were respectively:
for dusty fraction content $3 \%$
$\mathrm{SE}_{4 \max }-\mathrm{SE}_{4 \min }=72 \%-54 \%=18 \%$
for dusty fraction content $7 \%$
$\mathrm{SE}_{4 \max }-\mathrm{SE}_{4 \min }=42 \%-26 \%=16 \%$
for dusty fraction content $11 \%$
$\mathrm{SE}_{4 \max }-\mathrm{SE}_{4 \min }=27 \%-18 \%=9 \%$

Considering that the lowest point in each of the three series represents the situation in which $\mathrm{SE}_{4}=\mathrm{SE}$ [9] means that the value difference in sand equivalents for $0 / 2$ and $0 / 4 \mathrm{~mm}$ can be up to $20 \%$ (the difference between the value in the percentages). 


\section{Compressibility and bearing capacity of mineral mixtures}

From the standpoint of the durability of pavement construction, apart from analyses of the sand equivalent for road substructures, their density and load capacity are also significant. A parameter describing these features is the CBR capacity index. It is closely related to the grading of a given mixture and thus also to the sand equivalent.

The minimum values of the sand equivalent, given in various regulations, range between $30 \%$ and $45 \%$. To determine which of these values is correct, it was decided to look for a link between the sand equivalent and the load capacity of the mixture.

For each of the six blends described in section 3.1., a Proctor test was performed [7] followed by a CBR [8]. The results are presented in Table 3.

Tab. 3. Summary of research results for mineral mixtures.

\begin{tabular}{|c|c|c|c|c|c|c|c|}
\hline \multirow{2}{*}{ Examined feature } & \multirow{2}{*}{ Unit } & \multicolumn{6}{|c|}{ The content of dusty fraction in mineral mixture } \\
\hline & & $0 \%$ & $3 \%$ & $5 \%$ & $7 \%$ & $9 \%$ & $11 \%$ \\
\hline $\begin{array}{l}\text { Sifting \# [mm] } \\
31,5 \\
16 \\
8 \\
4 \\
2 \\
1 \\
0,5 \\
0,063\end{array}$ & {$[\%]$} & $\begin{array}{l}100 \\
70 \\
50 \\
39 \\
31 \\
19,3 \\
12,1 \\
0 \\
\end{array}$ & $\begin{array}{l}100 \\
70 \\
50 \\
39 \\
31 \\
20,5 \\
13,9 \\
3 \\
\end{array}$ & \begin{tabular}{|l}
100 \\
70 \\
50 \\
39 \\
31 \\
21,2 \\
15,2 \\
5 \\
\end{tabular} & $\begin{array}{l}100 \\
70 \\
50 \\
39 \\
31 \\
22 \\
16,4 \\
7 \\
\end{array}$ & $\begin{array}{l}100 \\
70 \\
50 \\
39 \\
31 \\
22,7 \\
17,6 \\
9 \\
\end{array}$ & $\begin{array}{l}100 \\
70 \\
50 \\
39 \\
31 \\
23,5 \\
18,8 \\
11 \\
\end{array}$ \\
\hline $\begin{array}{l}\text { Sand equivalent } \\
\text { SE (2001) } \\
\text { SE4 (2001) } \\
\text { SE(10) (2015) } \\
\text { SE4 (2015) }\end{array}$ & {$[\%]$} & $\begin{array}{l}100 \\
100 \\
100 \\
100 \\
\end{array}$ & $\begin{array}{l}54 \\
61 \\
54 \\
61 \\
\end{array}$ & $\begin{array}{l}35 \\
40 \\
53 \\
54 \\
\end{array}$ & $\begin{array}{l}26 \\
32 \\
51 \\
53 \\
\end{array}$ & $\begin{array}{l}21 \\
24 \\
53 \\
51\end{array}$ & $\begin{array}{l}18 \\
22 \\
52 \\
52 \\
\end{array}$ \\
\hline $\begin{array}{l}\text { Compactibility } \\
\mathrm{w}_{\text {opt }} \\
\rho_{0 \mathrm{~s} \max }\end{array}$ & $\begin{array}{l}{[\%]} \\
{\left[\mathrm{g} / \mathrm{cm}^{3}\right.}\end{array}$ & $\begin{array}{l}9,6 \\
2,011\end{array}$ & $\begin{array}{l}9,4 \\
2,114\end{array}$ & $\begin{array}{l}8,8 \\
2,142\end{array}$ & $\begin{array}{l}8,3 \\
2,175\end{array}$ & $\begin{array}{l}8,1 \\
2,174\end{array}$ & $\begin{array}{l}8,2 \\
2,163\end{array}$ \\
\hline $\begin{array}{l}\text { Load index } \\
\text { CBR }\end{array}$ & {$[\%]$} & 76,8 & 105,2 & 147,7 & 156,2 & 141,4 & 105,7 \\
\hline
\end{tabular}

In accordance with the requirements $[4,5,6,12]$, a mixture with a loading index greater than $80 \%$ and an auxiliary substructure greater than $60 \%$ is suitable for the basic substructure. This means that a mixture with a dust content of $0 \%$ can only be applied to the substructure. Other mixtures with dust content of $3 \div 11 \%$ fulfilled the requirements as for the basic framework. Analysis of the results shows that with a dust content of $7 \%\left(\mathrm{SE}_{42001}=\right.$ $40 \%$ ) the highest skeletal density was obtained and the highest load capacity ratios. Capacity of blends with a dust content of less than $3 \%\left(\mathrm{SE}_{42001}>61 \%\right)$ are almost twice as large as the capacity of the dust blends $5 \div 9 \%\left(\mathrm{SE}_{42001}=40 \% \div 24 \%\right)$.

The relationship between the CBR and sand indexes is shown in Figure 5. Of the six analyzed blends, only one with a dust content of $3 \%$ fulfilled all the requirements of the basic substructure in accordance with WT-4. The criteria in OST [6] fulfilled two blends with a dust content of 3\% and 5\%. In accordance with the 1997 standard [4], three of the blends tested, with a dust content of $3 \%, 5 \%$, and $7 \%$, can be used for the basic framework. 


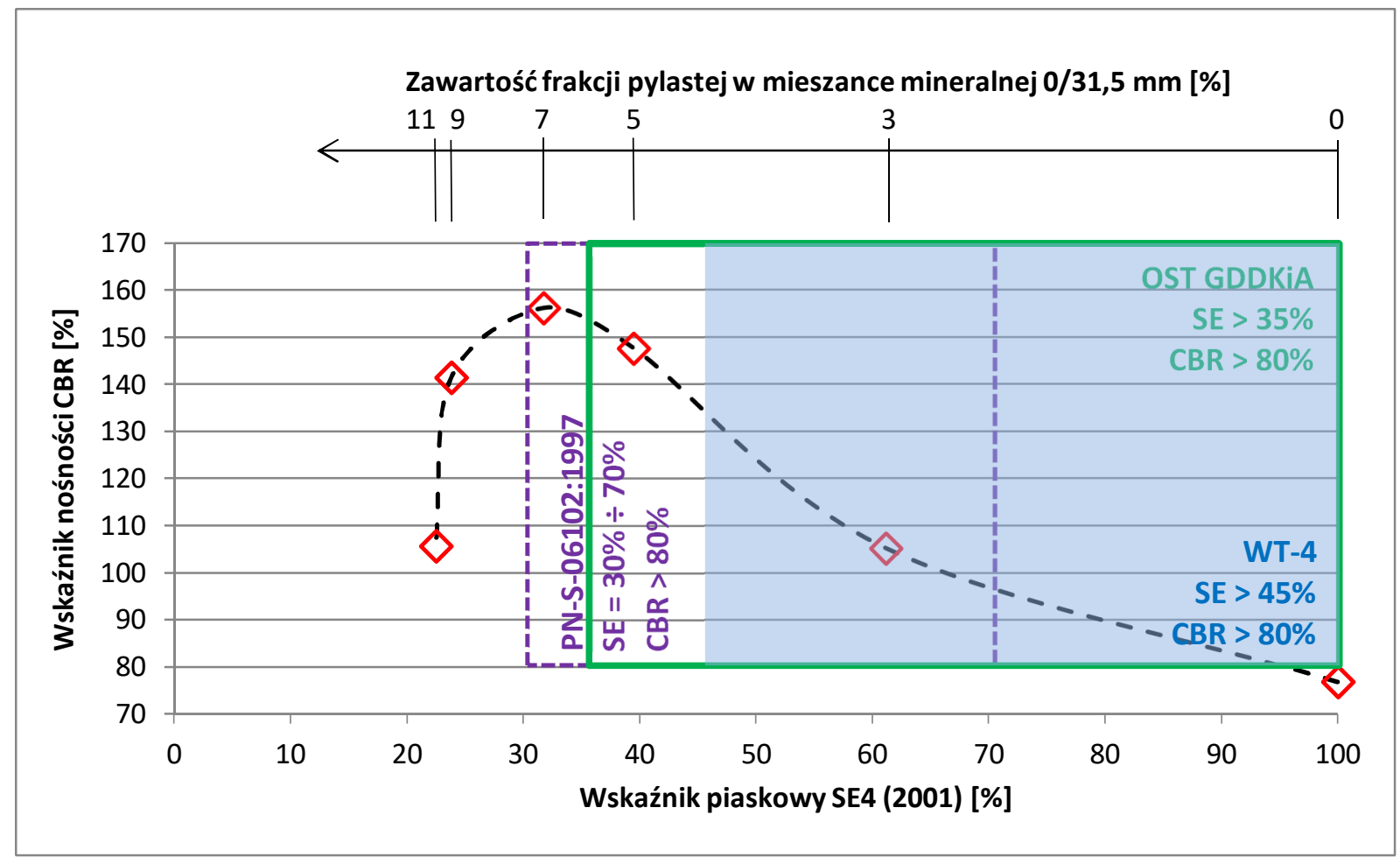

5. Changes in the CBR capacity index depending on the sand equivalent $\mathrm{SE}_{42001}$ and requirements for essential bases according to different regulations $[5,6,12]$

The results show that in the preparation of laboratory samples using dust extraction, the SE4 (2015) method, regardless of the actual dust content of the mixture, gives a similar value to the sand index. It follows that such an assessment is not valid and should not be used to assess the suitability of mixtures for use in road surfaces.

According to the authors, the sand equivalent determined on samples of grain size $0 / 4$ $\mathrm{mm}$ without correction of their composition is the most objective way of determining this parameter due to the subsequent application of the material in real conditions. In practice, the substructure does not have the ability or purpose to sift dusty particles. However, laboratory tests should reproduce (model) the work of the layer in real conditions as far as possible.

Highest loading capacity was obtained for blends containing 5-9\% dusty fraction. Such blends are characterized by a sand equivalent of $25-40 \%$ for testing the $0 / 4 \mathrm{~mm}$ fraction without weeding out the dust. Therefore, it should be noted that when evaluating the sand equivalent according to SE4 (2001), the recommended minimum value for this parameter should be about $30 \%$. On the other hand, the excessive value of the sand ratio leads to a decrease in the load capacity and a decrease in the density of the mixture. Therefore, for fractional analysis of $0 / 4$ without seeding fraction of SE4 (2001), the maximum value of the sand equivalent should be $70 \%$.

\section{Summary of research}

- Any mineral blend, tested in accordance with the 2015 standard [11], complies with the WT-4 requirements for the sand equivalent basis. Correction of dusty content is an inappropriate way to prepare a sample for a sand equivalent. The weeding out of the test specimen according to the standard [11] leads to a change in the grain composition of the material and a significant overestimation of the results. Sand equivalent values will always be above $50 \%$ irrespective of the dust content of the mixture. 
- In all technical guidelines and specifications it is important to clearly specify whether the test criteria given on a sample of $0 / 2 \mathrm{~mm}$ or $0 / 4 \mathrm{~mm}$.

- Due to optimal mineral density and the highest load capacity, the dust content should be within the range of $5 \div 7 \%$. This corresponds to a sand equivalent, marked at $0 / 4 \mathrm{~mm}$, within the limits $\mathrm{SE}_{4} \approx 30 \div 40 \%$.

- Mineral compositions with too low dust content are characterized by lower density and load capacity than those with the optimum content of this fraction. Blends with a dust content of less than 3\% should not be used. This means that sand equivalents minerals should be used for the paving $\mathrm{SE}_{4}<70 \%$.

- The method of SE4 (2001) should be used for the evaluation of the sand equivalent, at a fraction of $0 / 4 \mathrm{~mm}$ without particulate dust fraction and the corresponding sand equivalent limit values are min. $30 \%$, $\max 70 \%$.

\section{Conclusions}

Laboratory tests have been conducted to determine that the use of dust extraction in the WP test is inappropriate. Based on the study cycle, a standardized assessment of aggregates and mineral mixtures was proposed for the sand equivalent. SE4 (2001) results provide objective results correlated with the compactness and carrying capacity of the materials analyzed. The new SE4 Sand Index (2001) has been developed. The results of the study are promising and the further extension of the scope of research, eg for the analysis of aggregates from other quarries, should confirm the observed dependencies..

According to the authors of the article, the most appropriate solution seems to be the standard adopted in PN-S-06102: 1997 [12]. The sand equivalent for mineral mixtures intended for unbound layers should be tested at fraction $0 / 4$ without adjusting the dust content. Aggregates or mixtures irrespective of the type of layer to be used should have a minimum sand content of not less than $30 \%$. The maximum value of the indicator should also be set, and the $70 \%$ proposed in the standard [12] is reasonable.

\section{Source materials}

[1] A. NIKOLAIDES, E. MANTHOS, M. SARAFIDOU, "Sand equivalent and methylene blue value of aggregates for highway engineering", Foundations of civil and environmental engineering, No. 10, 2007.

[2] BN-64/8931-01 Drogi samochodowe. Oznaczanie wskaźnika piaskowego.

[3] Department of Transportation Division of Engineering Services, "Method of test for sand equivalent", California Test 217, June 2008.

[4] Katalog typowych konstrukcji nawierzchni podatnych i półsztywnych Załącznik do zarządzenia Nr 31 Generalnego Dyrektora Dróg Krajowych i Autostrad z dnia 16.06.2014r.

[5] Mieszanki niezwiązane do dróg krajowych. WT-4 2010. Wymagania Techniczne. Załącznik Nr 3 do Zarządzenia Nr 102 Generalnego Dyrektora Dróg Krajowych i Autostrad z dnia 19 listopada 1010r.

[6] Ogólne Specyfikacje Techniczne (OST). Warstwy konstrukcyjne nawierzchni z mieszanek kruszyw niezwiązanych zagęszczanych mechanicznie - 2014 r. GDDKiA.

[7] PN-EN 13286-2:2010 Mieszanki niezwiązane i związane hydraulicznie. Metody badań laboratoryjnych gęstości na sucho i zawartości wody. Zagęszczanie metodą Proctora.

[8] PN-EN 13286-47:2012 Mieszanki niezwiązane i związane spoiwem hydraulicznym. Metoda badania do określenia kalifornijskiego wskaźnika nośności, natychmiastowego wskaźnika nośności i pęcznienia liniowego. 
[9] PN-EN 933-8:2001 Badania geometrycznych właściwości kruszyw. Ocena zawartości drobnych cząstek. Badanie wskaźnika piaskowego.

[10] PN-EN 933-8:2012 Badania geometrycznych właściwości kruszyw. Ocena zawartości drobnych cząstek. Badanie wskaźnika piaskowego.

[11] PN-EN 933-8:2015 Badania geometrycznych właściwości kruszyw. Ocena zawartości drobnych cząstek. Badanie wskaźnika piaskowego.

[12] PN-S-06102:1997 Drogi samochodowe. Podbudowy z kruszyw stabilizowanych mechanicznie.

[13] Texas Department of Transportation, Construction Division, "Test Procedure for sand equivalent test, TEX-203-F”, Texas , January 2016. 